\title{
Vector-borne helminths of dogs and humans - focus on central and eastern parts of Europe
}

\author{
Aleksander Masny ${ }^{*}$ Elżbieta Gołąb, Danuta Cielecka and Rusłan Sałamatin
}

\begin{abstract}
Comments on the article "Vector-borne helminths of dogs and humans in Europe" published in Parasites and Vectors 2013, 6:16.
\end{abstract}

Keywords: Dirofilaria repens, Dirofilaria immitis, Acanthocheilonema reconditum, Human dirofilariosis, Autochthonous

\section{Dear Editor,}

Vector-borne helminths (VBH) of dogs and humans are becoming recognized as an emerging problem in many parts of Europe, a situation which is reflected by the growing number of published reports from different countries. Review articles are an important means of presenting the current state of knowledge in the field. The article "Vector-borne helminths of dogs and humans in Europe" Parasites and Vectors 2013, 6:16 [1] provides an excellent description of various aspects of VBH. However it also suffers from referring to incomplete information regarding central and eastern parts of Europe.

We would like to present data from Poland and Ukraine, omitted by the authors of the review, and correct information published in some of the cited articles. An analysis of the human cases of dirofilariosis caused by Dirofilaria repens detected in Poland was performed [2]. As a result, three undoubtedly autochthonous cases of human D. repens infection were found in the Mazovia region, i.e. in the central part of Poland till the end of 2011 [2]. In this region, canine dirofilariosis is present $[3,4]$. The first autochthonous human case was recorded in 2010 in Grójec $\left(51^{\circ} 51^{\prime} \mathrm{N}, 20^{\circ} 52^{\prime} \mathrm{E}\right)$, and the next two in 2011 in Warszawa $\left(52^{\circ} 35^{\prime} \mathrm{N}, 21^{\circ} 05^{\prime} \mathrm{E}\right)$ and Białobrzegi $\left(51^{\circ} 39^{\prime} \mathrm{N}, 20^{\circ} 52^{\prime} \mathrm{E}\right)$. In the majority of the recognized cases (15 out of 18), the possibility of the infection taking place outside of Poland could not be excluded $[2,5,6]$ and some of those cases were incorrectly reported as autochthonous [7]. We found a significant increase in the

\footnotetext{
*Correspondence: amasny@gmx.com

Department of Medical Parasitology, National Institute of Public HealthNational Institute of Hygiene, 24 Chocimska, 00-791, Warszawa, Poland
}

number of recognized human $D$. repens infections - 13 new cases in the period 2009-2011 [2].

The data on human dirofilariosis cases from Ukraine were omitted in the review [1]. We estimated that over $60 \%, 900$ out of approximately 1500 described in the literature, European human cases of $D$. repens infection were detected in Ukraine $[2,8]$. These data show a shift in the endemic territory of $D$. repens. Further investigations of the epidemiological situation in central and eastern Europe could be crucial to determine the directions of the spread of dirofilariosis across the continent. Is dirofilariosis spreading from East to West or is it migrating from multiple directions towards central and northern Europe? The first autochthonous case of canine $D$. repens infection in Germany was identified in 2004, in the south-western part of the country [9]. It was suggested that the infection might spread from the south to the north of Germany, however, it was found that one of the infected dogs was brought from central Poland [10]. D. repens infections were confirmed to be autochthonous in dogs in central Poland, close to Warszawa in 2009 [3,4]. Therefore the question concerning the routes of spreading of $D$. repens in Europe remains open.

The first autochthonous case of canine D. immitis infection was detected in northern Poland (Gdynia, $54^{\circ} 30^{\prime} \mathrm{N}, 18^{\circ} 32^{\prime} \mathrm{E}$ ) in March 2012 [11]. This case indicated a new northern border of autochthonous canine D. immitis in continental Europe for 2012.

Moreover, our data can fill one of the blank spots on the European map of distribution of Acanthocheilonema reconditum, presented in the review [1]. The parasite 
was detected in 2011 in two dogs form central Poland during a screening of dogs for dirofilariosis [12].

\section{Competing interests}

The authors declare that they have no competing interests.

\section{Authors' contributions}

All authors analyzed data on dirofilariosis in central and eastern Europe. DC and RS performed review of articles published in Ukrainian and Russian languages. AM and EG wrote the letter following the discussion with DC and RS. All authors approved the final version of the manuscript.

\section{Acknowledgements}

Financial support for publication fees came from Polish National Science

Centre project No. N404 256840

Received: 11 February 2013 Accepted: 12 February 2013

Published: 22 February 2013

\section{References}

1. Otranto D, Dantas-Torres F, Brianti E, Traversa D, Petrić D, Genchi C, Capelli G: Vector-borne helminths of dogs and humans in Europe. Parasit Vectors 2013, 6:16 [http://dx.doi.org/10.1186/1756-3305-6-16]

2. Cielecka D, Żarnowska-Prymek H, Masny A, Salamatin R, Wesołowska M, Gołąb E: Human dirofilariosis in Poland: the first cases of autochthonous infections with Dirofilaria repens. Ann Agric Environ Med 2012, 19:445-450.

3. Demiaszkiewicz AW, Polańczyk G, Pyziel AM, Kuligowska I, Lachowicz J: The first foci of dirofilariosis of dogs evoked by Dirofilaria repens Railliet et Henry, 1911 in central Poland. Wiad Parazytol 2009, 55:367-370. In Polish.

4. Masny A, Lewin T, Salamatin R, Golab E: Autochthonous canine Dirofilaria repens in the vicinity of Warsaw. Pol J Vet Sci 2011, 14:659-661 [http://dx. doi.org/10.2478/v10181-011-0098-4]

5. Żarnowska-Prymek H, Cielecka D, Salamatin R: [Dirofilariasis - Dirofilaria repens - first time described in Polish patients]. Przegl Epidemiol 2008, 62:547-551. In Polish.

6. Wesolowska M, Kisza K, Szalinski M, Zielinski M, Okulewicz A, Misiuk-Hojlo M, Szostakowska B: First case of heterochthonous subconjunctival dirofilariasis described in Poland. Am J Trop Med Hyg 2010, 83:210 [http:// dx.doi.org/10.4269/ajtmh.2010.10-0084]

7. Genchi C, Kramer LH, Rivasi F: Dirofilarial infections in Europe. Vector Borne Zoonotic Dis 2011, 11:1307-1317 [http://dx.doi.org/10.1089/vbz.2010.0247]

8. Pavlikovs'ka T, Nikolaênko S: Aktual'nì problemi transmìsivnih parazitoziv. SES Profilaktična medicina 2011, 4:68-71. In Ukrainian.

9. Hermosilla C, Pantchev N, Dyachenko V, Gutmann M, Bauer C: First autochthonous case of canine ocular Dirofilaria repens infection in Germany. Vet Rec 2006, 158:134-135 [http://dx.doi.org/10.1136/vr.158.4.134]

10. Pantchev N, Norden N, Lorentzen L, Rossi M, Rossi U, Brand B, Dyachenko V: Current surveys on the prevalence and distribution of Dirofilaria spp. in dogs in Germany. Parasitol Res 2009, 105(Suppl 1):63-74 [http://dx.doi.org/ 10.1007/s00436-009-1497-7]

11. Świątalska A, Demiaszkiewicz AW: First autochthonous case of Dirofilaria immitis invasion in dog in Poland. Życie Weterynaryjne 2012, 87:685-686. In Polish.

12. Masny A, Lewin T, Salamatin R, Golab E: The first report on detection of canine Acanthocheilonema reconditum in Poland and the associated diagnostic problems. Pol J Vet Sci 2011, 14:485-487 [http://dx.doi.org/ 10.2478/v10181-011-0073-0]

doi:10.1186/1756-3305-6-38

Cite this article as: Masny et al:: Vector-borne helminths of dogs and humans - focus on central and eastern parts of Europe. Parasites \& Vectors 2013 6:38.

\section{Submit your next manuscript to BioMed Central and take full advantage of:}

- Convenient online submission

- Thorough peer review

- No space constraints or color figure charges

- Immediate publication on acceptance

- Inclusion in PubMed, CAS, Scopus and Google Scholar

- Research which is freely available for redistribution 